\title{
Pharmacokinetic properties of clarithromycin: A comparison with erythromycin and azithromycin
}

\author{
MARC LEBEL, PHARMD, FCCP
}

\begin{abstract}
M LEBEL. Pharmacokinetic properties of clarithromycin: A comparison with erythromycin and azithromycin. Can J Infect Dis 1993;4(3):148-152.

OвJестrv: To compare the pharmacokinetic properties of two new macrolide antibiotics, clarithromycin and azithromycin, with those of the prototype macrolide, erythromycin. Data SouRces: Primarily peer review journals were searched for papers describing the pharmacokinetics of these new macrolides. STUDY Selection: Fifteen in vitro and clinical studies of clarithromycin and azithromycin and one clinical abstract on clarithromycin from the past four years were selected for review. Data Extraction: Data relevant to the pharmacokinetic characteristics of clarithromycin, azithromycin and, to a lesser extent, erythromycin were selected for presentation in this comparison. Data Synthesis: By reviewing the available studies, it was possible to construct pharmacokinetic profiles of the new compounds, and to compare them with each other and with erythromycin. Conclusions: Both clarithromycin and azithromycin have been shown to have an antibacterial spectrum and pharmacokinetic profile superior to that of erythromycin. The differences between the new compounds, however, may not be that significant. Each is likely to become a first-line therapeutic option in specific instances, which will become better delineated as clinical research on these new macrolides continues.
\end{abstract}

Key Words: Azithromycin, Clarithromycin, Erythromycin, Macrolides, Pharmacokinetics

\section{Propriétés pharmacocinétiques de la clarithromycine : Comparaison avec l'érythromycine et l'azithromycine}

\begin{abstract}
OBJECTIF : Comparer les propriétés pharmacocinétiques de deux nouveaux macrolides, soit la clarithromycine et l'azithromycine, avec celles du macrolide prototype érythromycine. Sources Des DonNéEs : Des publications scientifiques avec comité de révision scientifique ont principalement été passées en revue et on y a sélectionné des articles sur la pharmacocinétique de ces nouveaux macrolides. SÉLEction DEs ÉTUDEs : Quinze études in vitro et cliniques sur la clarithromycine et l'azithromycine et un résumé clinique sur la clarithromycine publiés au cours des quatre dernières années ont été passés en revue. ExTRACTion DES DONNÉES: Des données relatives aux caractéristiques pharmacocinétiques de la clarithromycine, de l'azithromycine et, dans une proportion plus faible, de l'érythromycine, ont été choisies aux fins de cet article comparatif. Synthèse des données : En passant en revue les études disponibles, il a été possible de dresser un profil pharmacocinétique des nouveaux composés et de les comparer entre eux, de même qu'avec l'érythromycine. Conclusions: La clarithromycine et l'azithromycine se sont toutes deux dotées d'un spectre antibactérien et d'un profil pharmacocinétique supérieur à ceux de l'érythromycine. Les différences entre ces deux nouveaux produits ne sont nécessairement significatives. Chacun est susceptible de devenir un choix thérapeutique de première ligne dans certains cas spécifiques qui seront définis plus précisément à mesure que la recherche clinique se poursuivra.
\end{abstract}

Laboratoire de Pharmacocinétique Clinique, Université Laval, École de pharmacie, Cité Universitaire, Québec, Québec

Correspondence: Dr Marc LeBel, Professeur et Directeur, Laboratoire de Pharmacocinétique Clinique, Université Laval; École de pharmacie, Cité Universitaire, Québec, Québec G1K 7P4. Telephone (418) 656-3158, Fax (418) 656-2305

Received for publication September 4, 1992. Accepted December 24, 1992 
$\mathrm{E}$ RYTHROMYCIN IS COMMONLY USED TO TREAT A VARIETY OF infections, including those of the respiratory tract. Although the compound is effective against a fairly broad range of organisms (including atypical pathogens), its clinical success may be limited by erratic low blood and tissue levels, and a tid to qid dosing schedule. In addition, patients complain frequently of gastrointestinal adverse effects associated with erythromycin. A number of congeners are now in development (and one, clarithromycin, is available in Canada) that promise to improve upon the antibiotic spectrum, pharmacokinetics, safety, and tolerability of erythromycin.

Clarithromycin is an acid-stable analogue of erythromycin with a methoxy substitution at C-6 of the erythronolide ring. This structural alteration prevents acid-induced conversion of the molecule to inactive spiroketal forms in the stomach and improves bioavailability and gastrointestinal tolerance after an oral dose. It therefore increases antibacterial activity (1) compared with erythromycin. Clarithromycin has demonstrated bactericidal activity against both typical and atypical respiratory pathogens.

When clarithromycin is metabolized in humans, a microbiologically active metabolite, 14-hydroxy clarithromycin, is formed. This active metabolite has been shown to contribute an additive or synergistic effect to the activity of the parent compound in vivo against selected pathogens. Results from in vitro and in vivo testing of the combined compounds suggest that routine in vitro susceptibility tests and animal efficacy studies with clarithromycin alone may underestimate its potential efficacy against Haemophilus influenzae (2).

Azithromycin, a 15-membered macrolide that is classified as the first azalide, differs from erythromycin by the insertion of a methyl-substituted nitrogen into position 9a of the large aglycone ring. The insertion of the nitrogen into the ring distinguishes azalides from macrolides (which have only carbon- and oxygen-containing rings), and significantly alters the chemical, microbiological, and pharmacokinetic properties of these compounds (3).

This paper compares the pharmacokinetic properties of these new compounds, clarithromycin and azithromycin, with those of erythromycin.

\section{ABSORPTION}

Erythromycin base is incompletely but adequately absorbed from the upper part of the small intestine, and it is inactivated by gastric acid. The drug is therefore administered as enteric-coated formulations or as esters stable to gastric acid, eg, erythromycin estolate or ethylsuccinate. Bioavailability, generally about $25 \%$ of an oral dose (3), is decreased when erythromycin base or stearate is administered with food (4). As shown in Table 1 , maximum concentration of 1.9 to $3.8 \mu \mathrm{g} / \mathrm{mL}$ and $3.08 \mu \mathrm{g} / \mathrm{mL}$ are attained with erythromycin base and estolate $500 \mathrm{mg}$ single dosing.

Both clarithromycin and azithromycin have been shown to have pharmacokinetic profiles superior to that of erythromycin (Table 1). These new compounds have a more predictable pattern of absorption than the prototype. After an oral dose, clarithromycin reaches peak serum concentrations within $2 \mathrm{~h}$, azithromycin within $2.5 \mathrm{~h}$, and both achieve higher concentrations in tissue than in serum. In trials evaluating the effect of food on the disposition of clarithromycin, it was found that food may enhance absorption and bioavailability of the drug from 55 to $70 \%(1,5-6)$. Clarithromycin is stable in gastric acid. Steady-state peak serum concentrations are 1.0 to $1.5 \mathrm{mg} / \mathrm{L}$ after a $250 \mathrm{mg}$ twice-daily dose, and 2.0 to $3.0 \mathrm{mg} / \mathrm{L}$ after a $500 \mathrm{mg}$ twice-daily dose.

The bioavailability of a $500 \mathrm{mg}$ oral dose of azithromycin is only about $37 \%$, and peak serum concentration attained is $0.4 \mathrm{mg} / \mathrm{L}$ (7). Serum concentrations with multiple-dose regimens were slightly higher, but always below $1 \mathrm{mg} / \mathrm{L}$. Studies of the influence of food on azithromycin absorption revealed that peak serum concentration decreased by $52 \%$ and area under the plasma concentration-time curve (AUC) diminished by $43 \%(8)$.

There are apparent discrepancies between bioavailability and peak plasma concentration $\left(\mathrm{C}_{\max }\right)$ values for erythromycins, clarithromycin, and azithromycin because no equivalent intravenous formulations exist for erythromycin. Lactobionate and gluceptate intravenous erythromycins are not fully equivalent. Thus, bioavailability values for erythromycin and erythromycin estolate are only approximate.

\section{TABLE 1}

Mean pharmacokinetic parameters of erythromycin, azithromycin and clarithromycin following a single dose in healthy volunteers*

\begin{tabular}{|c|c|c|c|c|}
\hline Parameter & $\begin{array}{l}\text { Erythromycin base } \\
(500 \mathrm{mg})\end{array}$ & $\begin{array}{l}\text { Erythromycin estolate** } \\
(500 \mathrm{mg})\end{array}$ & $\begin{array}{l}\text { Azithromycin } \\
(500 \mathrm{mg})\end{array}$ & $\begin{array}{c}\text { Clarithromycin } \\
(500 \mathrm{mg})\end{array}$ \\
\hline Bioavailabliity (\%) & $\sim 25$ & $\sim 25^{\dagger}$ & 37 & 55 \\
\hline$C_{\max }(\mu \mathrm{g} / \mathrm{L})$ & $1.9-3.8$ & 3.08 & 0.4 & 1.6 \\
\hline$T_{\max }(h)$ & $1-5$ & 2.65 & 2.5 & $1.7-1.9$ \\
\hline $\mathrm{AUC}(\mu \mathrm{g} \mathrm{h} / \mathrm{L})$ & $5.8-11.2$ & 20.39 & $3.39^{\dagger}$ & $4-4.2$ \\
\hline Protein binding (\%) & $26-35$ & 75 & $7-50^{\S}$ & $65-75$ \\
\hline half-life (h) & $1.5-3.0$ & 3.0 & $11-14$ & $2.6-2.7$ ๆ \\
\hline
\end{tabular}

"Results are reported as mean $\pm S D$ where available. ${ }^{\dagger} A U C_{0-72 .}{ }^{*}$ Varies with formulation, salt form, and relation to meals. ${ }^{\delta}$ May change with serum concentration. "May increase with increasing doses. AUC area under the curve; $C_{\text {max }}$ maximum concentration; $T_{\max }$ time to maximum concentration. "Erythromycin estolate data from Croteau D, Bergeron MG, LeBel M. Antimicrob Agents Chemother 1988;32:567-5. 


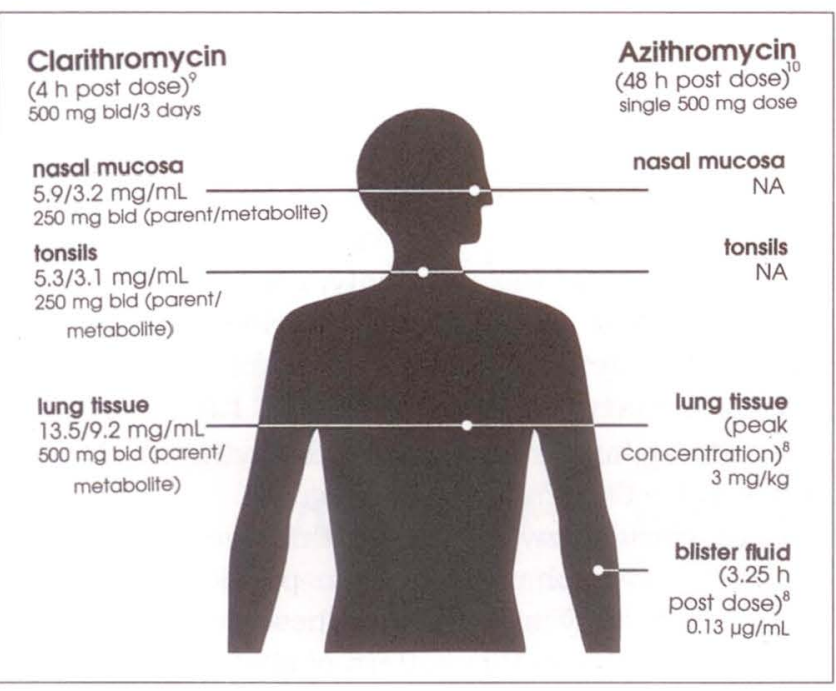

Figure 1) Tissue distribution of clarithromycin and azithromycin (Adapted from [20])

\section{DISTRIBUTION AND TISSUE PENETRATION}

Macrolide antibiotics are known to bind to plasma proteins, particularly alpha 1 -acid glycoprotein. These compounds are lipophilic, and they penetrate well into tissues (5).

Scaglione and Fraschini (9) evaluated the diffusion of clarithromycin into respiratory tissues, including the nasal mucosa, tonsils, and lungs, in adult patients undergoing surgery. For the three days preceding their surgical procedures, patients received clarithromycin, $250 \mathrm{mg}$ twice daily (nasal mucosa or tonsillar tissue), or $500 \mathrm{mg}$ twice daily (lung parenchyma). For clarithromycin and its active metabolite, terminal disposition half-life $(\mathrm{t} 1 / 2 \mathrm{~b})$ values in sputum were 1.3- to 1.6-fold longer than those in serum. In tonsils, mean $4 \mathrm{~h}$ post dose parent and metabolite concentrations were 5.3 and $3.1 \mathrm{mg} / \mathrm{kg}$, respectively, and mean $12 \mathrm{~h}$ post dose values were 2.1 and $1.2 \mathrm{mg} / \mathrm{kg}$ (Figure 1). Parent and metabolite concentrations in nasal mucosa $4 \mathrm{~h}$ post dose were 5.9 and $3.2 \mathrm{mg} / \mathrm{kg}$, respectively, and mean $12 \mathrm{~h}$ post dose values were 2.2 and 1.5 $\mathrm{mg} / \mathrm{kg}$. In lung tissue, parent and metabolite concentrations $4 \mathrm{~h}$ post dose were 13.5 and $7.2 \mathrm{mg} / \mathrm{kg}$, respectively, and $12 \mathrm{~h}$ post dose values were 2.8 and 2.0 $\mathrm{mg} / \mathrm{kg}$ (9). Significantly, these values exceed the $90 \%$ minimum inhibitory concentration (MIC90) for many respiratory pathogens (Table 2 ).

In a recent study conducted in the United Kingdom, pulmonary tissue concentrations of azithromycin were measured in 22 patients (10). Up to $96 \mathrm{~h}$ after a single $500 \mathrm{mg}$ dose, the following findings were observed: mean peak concentration of the drug in sputum, 1.56 $\mathrm{mg} / \mathrm{L}$; in bronchial mucosa, $3.89 \mu \mathrm{g} / \mathrm{mL}$; in alveolar macrophages, $23 \mathrm{mg} / \mathrm{L}$. Serum concentrations were significantly lower $(0.13 \mathrm{mg} / \mathrm{L} 12 \mathrm{~h}$ post dose), and were generally sub-MIC throughout the study period.

The concentration of azithromycin in most tissues has been shown to exceed serum concentra-
TABLE 2

In vitro $\mathrm{MIC}_{90}$ values of erythromycin, azithromycin and clarithromycin

\begin{tabular}{lccc}
\hline Bacteria & Erythromycin & $\begin{array}{c}\text { MIC90(mg/L) } \\
\text { Azithromycin }\end{array}$ & Clarithromycin \\
\hline $\begin{array}{c}\text { Staphylococcus } \\
\text { aureus }\end{array}$ & $>64.0$ & 1.0 & $>64.0$ \\
$\begin{array}{c}\text { Streptococcus } \\
\text { pneumoniae }\end{array}$ & $0.015-0.25$ & $0.015-0.25$ & $0.015-0.06$ \\
$\begin{array}{c}\text { Streptococcus } \\
\text { pyogenes }\end{array}$ & $0.03-4.0$ & $0.03-4.0$ & $0.015-0.25$ \\
$\begin{array}{c}\text { Moraxella } \\
\text { catarrhalis }\end{array}$ & 0.25 & 0.06 & $0.12-0.25$ \\
$\begin{array}{c}\text { Haemophilus } \\
\text { influenzae } \\
\text { Legionella } \\
\text { pneumophila }\end{array}$ & $2.0-8.0$ & $0.25-1.0$ & $0.25-8.0^{*}$ \\
\hline
\end{tabular}

"MIC90 of clarithromycin plus 14-OH metabolite: 0.25 - 2.0 (Adapted from Bahal N. Nahata M. Ann Pharmacother 1992;26:48)

tions by 10 - to 100 -fold (7). Single oral dose (500 mg) studies of azithromycin have found that the concentration of azithromycin in most tissues 12 to $48 \mathrm{~h}$ after dosing ranges from 1 to $9 \mathrm{mg} / \mathrm{kg}$ (3). Mean concentrations for a single tissue type are usually greater than $2.0 \mathrm{mg} / \mathrm{kg}$, and all tissue levels are higher than those of concurrently obtained serum samples. The average 'tissue' half-life is two to four days. One may question whether such an extended half-life is completely beneficial.

Although intraphagocytic bioactivity is not a common property of antimicrobial agents (11), the newer macrolide antibiotics achieve high intracellular concentrations. Both clarithromycin and azithromycin have been shown to penetrate macrophages and leukocytes, which makes them particularly effective against intracellular pathogens such as Legionella pneumophila and Chlamydia species (5). In contrast, penicillin and cephalosporin antibiotics are not actively concentrated by phagocytes, and they possess only modest, if any, intracellular activity (11).

Anderson and colleagues (11) observed that erythromycin was rapidly concentrated by neutrophils, with an intracellular to extracellular (I:E) ratio of 7:3. The I:E ratio for clarithromycin was 9:1. These investigators concluded that the superior pharmacokinetic properties of clarithromycin will lead to increased intraphagocytic accumulation and bioactivity in vivo.

Therapeutic concentrations of clarithromycin have also been found to stimulate protein kinase $\mathrm{C}$ activity in polymorphonuclear leukocytes (PMNLs). Thus, in addition to its antimicrobial activity, the drug stimulates cellular host defense mechanisms involving the activation of protein kinase C (12).

It was recently shown that, among all macrolides tested so far, azithromycin provides the highest I:E ratio, confirmed both in vitro and in vivo, with values of approximately 160 obtained in vitro for azithromycin 
(13). The theory that onsite, intraphagocytic delivery of azithromycin provides a significant amount of bioactive antimicrobial agent has been demonstrated in vitro and in vivo (14). However, this concept applies to all macrolides, including erythromycin, that are known to accumulate in phagocytic cells.

\section{METABOLISM AND ELIMINATION}

Although the metabolism of the macrolide antibiotics has not been extensively studied, it is known that a portion of the dose is metabolized in the liver. Macrolide antibiotics are demethylated by the cytochrome P-450-III microsomal enzyme system. Clarithromycin is metabolized to eight metabolites, but only one, the 14-hydroxy metabolite, has been shown to have antibacterial activity. The activity of this metabolite is comparable to or greater than that of the parent compound. The 14-hydroxy metabolite has been shown to act synergistically or additively with the parent compound, thereby extending clarithromycin's antimicrobial spectrum to include $H$ influenzae. It is not known whether any of the metabolites of azithromycin are active (5).

The pharmacokinetics of clarithromycin appear to be dose-dependent and nonlinear, apparently as a result of capacity-limited saturation of metabolic pathways. However, such nonlinearity is slight at the recommended dosages. Disproportionate increases in $\mathrm{C}_{\max }$, $\mathrm{t} 1 / 2 \mathrm{~b}$, and AUC have been reported in patients receiving a single high dose (1.2 g) or multiple doses. Similar dose dependency has been observed with the 14-hydroxy metabolite (1).

Thirty to $40 \%$ of an oral dose of clarithromycin is excreted unchanged or as an active metabolite via the kidneys, and the remainder is excreted via the bile (1). In individuals with normal renal function, the half-lives of clarithromycin and its 14-hydroxy metabolite after a $500 \mathrm{mg}$ dose are 5 and $7 \mathrm{~h}$, respectively (15). As renal function declines, the serum half-lives of these compounds increase to $7.7 \mathrm{~h}$ and $14 \mathrm{~h}$, respectively. At a creatinine clearance of 30 to $80 \mathrm{~mL} / \mathrm{min}$, clarithromycin's half-life is $12 \mathrm{~h}$, and this interval increases to $32 \mathrm{~h}$ when the creatinine clearance falls below $30 \mathrm{~mL} / \mathrm{min}$. For 14-hydroxy clarithromycin at the lower creatinine clearance, the half-life is $47 \mathrm{~h}$. Clearly, regimen alteration would be advisable in patients with severely impaired renal function.

Severe hepatic impairment could theoretically alter the pharmacokinetics of clarithromycin and its metabolite so that less metabolite would be formed, and renal clearance of the parent compound would increase. Steadystate levels of unchanged clarithromycin in hepatically impaired patients are similar to those in normal subjects, so if renal function is normal, the drug can be administered without dose adjustment (15).

Azithromycin elimination is polyphasic: the initial rapid decline in drug serum levels is followed by multiple-phase distribution and elimination. After a single $500 \mathrm{mg}$ dose, terminal half-life probably exceeds $40 \mathrm{~h}$ (16). When azithromycin metabolism occurs, demethylation is the primary route. The metabolites, which may number as many as 10 , are not thought to have any significant antimicrobial activity (3). Urinary excretion of unchanged azithromycin in humans appears to be a minor elimination route, usually amounting to less than $6 \%$ within $24 \mathrm{~h}$ after an oral $500 \mathrm{mg}$ dose. About $20 \%$ of the drug that reaches the systemic circulation is excreted unchanged in the urine (8). The feces are an important route of elimination for azithromycin; binary concentrations of the drug far exceed serum concentrations, suggesting binary excretion. Over half the drug-related material in the bile is unchanged. Transintestinal excretion may be the primary route of elimination of the unchanged compound (3).

Only 2 to $5 \%$ of an oral dose of erythromycin is excreted in active form in the urine. The antibiotic is metabolized through the liver and excreted in active form in the bile.

\section{DRUG REGIMENS}

The usual dose of erythromycin for adults ranges from 1 to $2 \mathrm{~g} /$ day, given in equally divided and spaced amounts, usually every $6 \mathrm{~h}$ (4).

Azithromycin may be given as a single $1 \mathrm{~g}$ dose in specific instances, but the more common regimen is a five-day course of therapy, beginning with a $500 \mathrm{mg}$ dose on day 1 , followed by daily $250 \mathrm{mg}$ doses on days 2 through $5(1,8)$.

For clarithromycin, the usual adult dose for infections of the respiratory tract and the skin and soft tissues is 250 to $500 \mathrm{mg}$ every $12 \mathrm{~h}$ for seven to 14 days. In patients with both hepatic and renal impairment, or in the presence of severe renal impairment, decreased dosage or prolonged dosing intervals may be appropriate (18).

\section{FUTURE OUTLOOK}

The pharmacokinetic advantages and superior spectra of activity of clarithromycin and azithromycin over erythromycin (base and esters) are well delineated; however, it is my opinion that differences between clarithromycin and azithromycin are not as dramatic as they may appear to be. Azithromycin's long half-life is not, in itself, an advantage. When evaluating tissue penetration of clarithromycin and azithromycin, one would prefer data from the same investigators under similar study conditions. Comparative studies are currently under way and are likely to provide further insights into understanding these new compounds.

Both clarithromycin and azithromycin offer therapeutic advantages in certain areas, and they are likely to become first-line therapy in a number of situations (17). The once- or twice-daily dosing regimens of these new macrolides may also improve patient compliance, a key factor in the management of any infection. 
ACKNOWLEDGMENTS: The author thanks David Guay, PharmD, Associate Professor of Pharmacy, University of Minnesota College of Pharmacy, Minneapolis, Minnesota, for his helpful comments during the development of this manuscript.

\section{REFERENCES}

1. Hardy DJ, Hensey DM, Beyer UM, et al. Clarithromycin: A unique macrolide. A pharmacokinetic, microbiological, and clinical overview. Diag Microbiol Infect Dis 1991;14:1-15.

2. Hardy DJ, Swanson RN, Rode RA, Marsh D, Shipkowitz NL, Clement JJ. Enhancement of the in vitro and in vivo activities of clarithromycin against Haemophilus influenzae by 14-hydroxy-clarithromycin, its major metabolite in humans. Antimicrob Agents Chemother 1990;34:1407-13.

3. Schentag JJ, Ballow CH. Tissue-directed pharmacokinetics. Am J Med 1991;91(Suppl 3A):5-11.

4. Gilman AG, Ball TW, Nies AS, Taylor P, eds. Goodman and Gilman's The Pharmacologic Basis of Therapeutics, 8th edn. New York: Pergamon Press, 1990:1130-4.

5. Bahal N, Nahata M. The new macrolide antibiotics: Azithromycin, clarithromycin, dirithromycin, and roxithromycin. Ann Pharmacother 1992;26:46-55.

6. Chu S-Y, et al. Drug-food interaction potential of clarithromycin: A new macrolide antimicrobial. J Clin Pharmacol 1991;32:32-6.

7. Foulds G, Shepard RM, Johnson RB, et al. The pharmacokinetics of azithromycin in human serum and tissues. J Antimicrob Chemother 1990;25(Suppl A):73-82.

8. Drew RH, Gallis HA. Azithromycin: Spectrum of activity, pharmacokinetics, and clinical applications. Pharmacotherapy 1992;12:161-73.

9. Scaglione F, Fraschini F. Distribution of clarithromycin and its metabolite $(14-\mathrm{OH})$ in therapeutically relevant respiratory tract tissues and fluids. First International Conference on the Macrolides, Azalides, and Streptogramins, Santa Fe, New Mexico, January 1992. (Abst)
10. Baldwin DR, Honeybourne J, Asby J, Wise R. Azithromycin concentrations at the sites of pulmonary infection. Eur Respir J 1990;3:886-90.

11. Anderson R, Joone G, van Rensburg. An in-vitro evaluation of the cellular uptake and intraphagocytic bioactivity of clarithromycin (A-56268, TE-031), a new macrolide antimicrobial agent. J Antimicrob Chemother 1988;22:923-33.

12. Pfleger S, Makristathis A, Block LH, et al. Clarithromycin stimulates intracellular killing of $S$ aureus 502 and respiratory burst of polymorphonuclear leukocytes via activation of protein kinase C. 17th International Congress of Chemotherapy, Berlin, Germany, June 1991:143. (Abst)

13. Bonnet $\mathrm{M}$, Van der Auwera $\mathrm{P}$. In vitro and in vivo intraleukocyte accumulation of azithromycin and its influence on ex vivo leukocyte chemiluminescence. Antimicrob Agents Chemother 1992;36:1302-9.

14. Gladue AE, Bright GM, Isaacson RE, Newborg MF. In vitro and in vivo uptake of azithromycin by phagocytic cells: Possible mechanism of delivery and release at site of infection. Antimicrob Agents Chemother 1989;33:277-82.

15. Neu H. The development of macrolides: Clarithromycin in perspective. J Antimicrob Chemother 1991;27(Suppl A): 1-9.

16. Periti P, Mazzei T, Mini E, Novelli A. Clinical pharmacokinetic properties of the macrolide antibiotics: Effects of age and various pathological states (Part II). Clin Pharmacokinetics 1989;16:262-82.

17. Piscitelli SC, Danziger LH, Rodvold KA, et al. Clarithromycin and azithromycin: New macrolide antibiotics. Clin Pharm 1992;11:137-52.

18. Biaxin Product Monograph. Montreal: Abbott Laboratories, 1992.

19. Croteau D, Bergeron, MG, LeBel M. Pharmacokinetic advantages of erythromycin estolate over ethylsuccinate as determined by high-pressure liquid chromatography. Antimicrob Agents Chemother 1988;32:561-5.

20. LeBel M. Pharmacokinetics of oral fluoroquinolones. In: ISI Atlas of Science: Pharmacology 1988:2;196-201. 


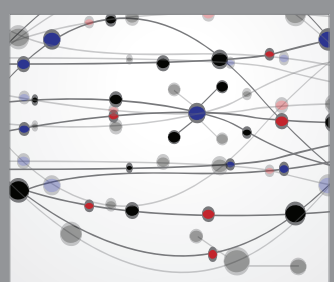

The Scientific World Journal
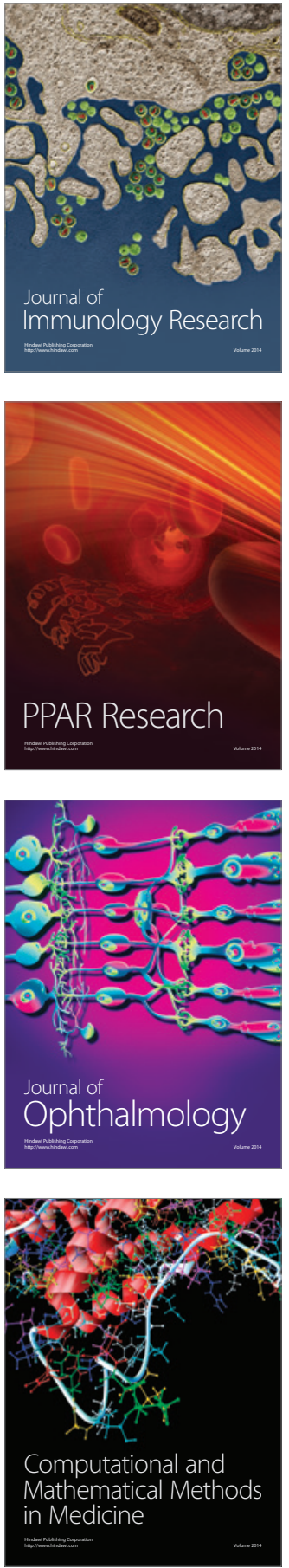

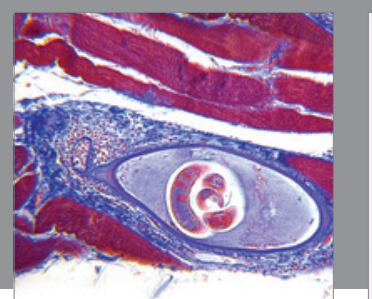

Gastroenterology Research and Practice

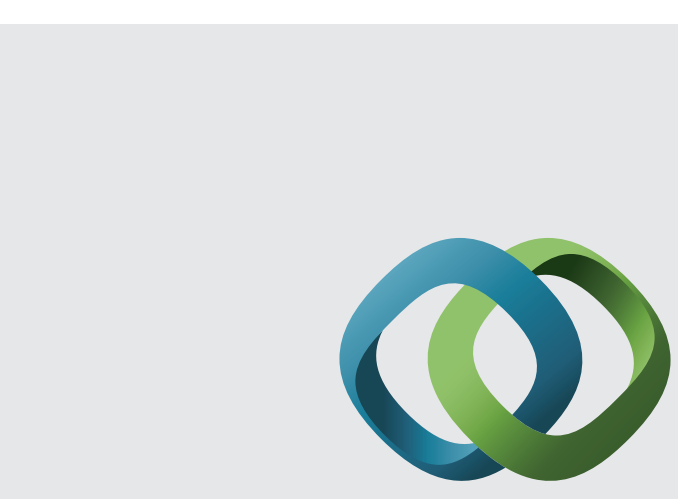

\section{Hindawi}

Submit your manuscripts at

http://www.hindawi.com
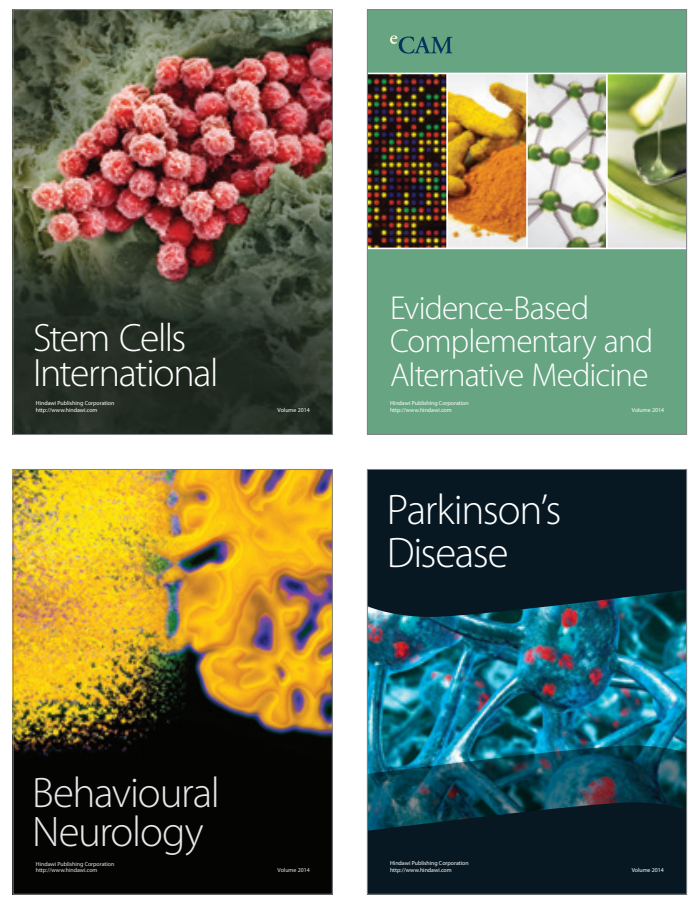
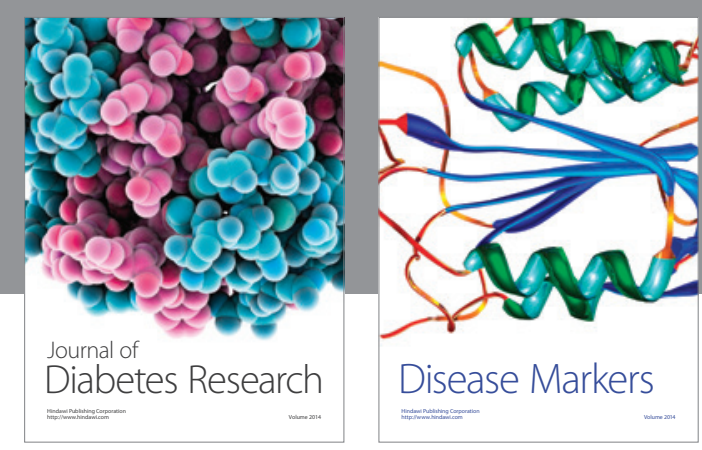

Disease Markers
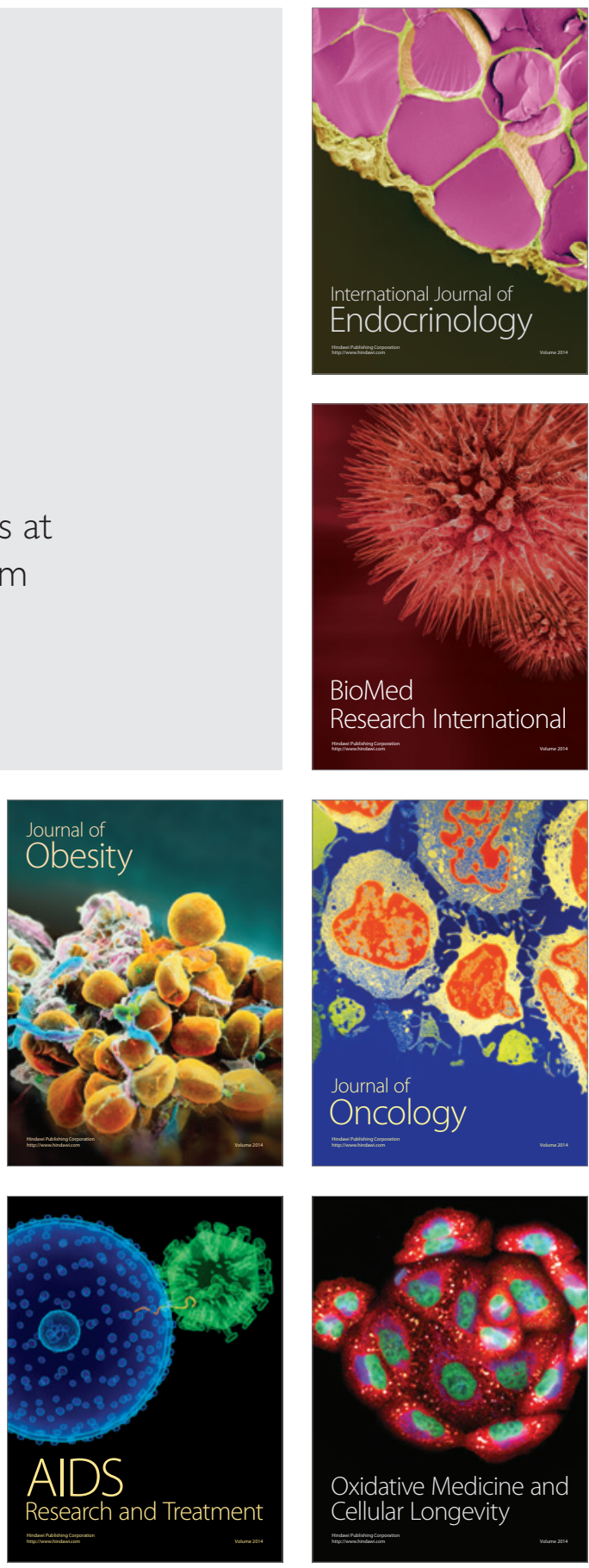